\title{
Cikkismertetés: Eszközök az egészségműveltség mérésére az általános populációban - rendszerezett szakirodalmi áttekintés
}

\author{
Article review: Assessment Tools for Health Literacy among the General \\ Population: A Systematic Review
}

Ismertető: $\quad$ Varga Szabolcs $\square$

Debreceni Egyetem Népegészségügyi Kar Megelőző Orvostani Intézet

Ismertetett cikk: Hongyan L, Huan Z, Yang S, et al. Assessment Tools for Health Literacy among the General Population: A Systematic Review. Int J Environ Res Public Health. 2018;15:1711. doi: 10.3390/ijerph15081711

Beküldve: $\quad$ 2019. 02. 22.

doi: $\quad$ 10.24365/ef.v60i2.427

Kulcsszavak: egészségműveltség; általános populáció; mérőeszköz

Keywords: health literacy; general population; assessment tool

Az ismertetett review cikk az általános populációban egészségműveltség mérésére alkalmazott eszközöket mutatja be. A szerzők kifejtik, hogy az egészségmúveltség „az emberek kognitív és szociális készsége, amely meghatározza az egyének motivációját és az egyének képességét, amely segítségével hozzáférnek, megértik és felhasználják azokat az információkat, amelyek elősegítik és fenntartják jó egészségüket". Az egészségi állapot egyik fontos determinánsa, ezért fejlesztése az egyik legalapvetőbb, leggazdaságosabb és leghatékonyabb módja az egészségfejlesztésnek, így mérőeszközeinek módosítása is nélkülözhetetlen. A 2003-as „National Assessment of Adult Literacy" felmérés kimutatta, hogy az USA-ban a felnőtt lakosság 14\%-ának alacsony az egészségműveltségi szintje. 2006-ban az Ausztrál Statisztikai Hivatal kutatása szerint az ausztrál felnőtt lakosság 60\%-ának, az első európai egészségmúveltség felmérés eredményei alapján pedig az európai lakosság 47\%-ának alacsony az egészségműveltsége. Kínában ugyanez az arány 91,2\%. Az alacsony szintű vagy nem megfelelő egészségmúveltség mára világméretű közegészségügyi problémává vált.

A rendszerezett szakirodalmi áttekintés során a PRISMA protokollt alkalmazták a szerzők. A folyóiratcikkek eléréséhez a Pubmed, Embase és a Web of Science adatbázisokat használták, hogy a 2010. január 10-ig publikált, az egészségmúveltséget általános populációban mérő eszközöket összegyújtsék. A kereséshez a "health literacy” keresőkulcsot alkalmazták. Azokat a publikációkat választották $\mathrm{ki}$, amelyek megfeleltek a következő kritériumoknak: (1) kifejlesztettek és validáltak egy egészségműveltséget mérő eszközt, (2) a 15 évnél idősebb, általános populációban alkalmazták azt. A mérőeszközök minőségének értékelését és a szakirodalom szűrését két független kutató végezte az előre meghatározott bekerülési kritériumok alapján. A kutatás során alkalmazott minőségértékelés 
a SURGE (Survey Criterium Guidelines) alapján történt, így 11 folyóiratcikk került további feldolgozásra.

Minden mérőeszköz kérdőív formájában méri az egészségműveltséget. A skálák fejlesztésének általános, többlépcsős folyamata a következő stádiumokból állt: itemek kidolgozása, előzetes tesztelés és az olvashatóság értékelése. A folyamat módszertani megoldásai különböztek az egyes eszközök esetében. A válaszadási arányok $61 \%$ és 99,5\% közöttiek voltak, a mintanagyságok is jelentős eltéréseket mutattak, 99-13,646 tartományban. A skálák belső konzisztenciája elfogadható mértékű volt minden esetben, azonban egyes alskáláknál már születtek gyengébb eredmények. [1. táblázat] A cikk megállapítása szerint az a trend figyelhető meg, hogy folyamatosan jelennek meg azok az új mérőeszközök, melyek multidimenzionálisan és széleskörűen mérik az egészségműveltséget. A mérésbe bevont dimenziók tekintetében azonban egyértelmü konszenzus nem alakult ki. A szerzők deklarált célja az volt, hogy bemutassák ezeket a különböző megközelítéseket, ezzel hozzájárulva az egészségműveltség átfogóbb és hatékonyabb kutatásához.

\section{TANULSÁGOK A HAZAI SZAKEMBEREK SZÁMÁRA}

A cikk legfontosabb tanulsága, hogy az alacsony egészségműveltség világméretű problémává vált, ezért kutatása fontos népegészségügyi téma. E terület mérésére mára már igen sokszínű, folyamatosan bővülő módszertani eszköztár áll rendelkezésre. 
1. táblázat: Az egészségműveltség skálák áttekintése

\begin{tabular}{|c|c|c|c|c|c|c|}
\hline Szerző és kiadás éve & Skála neve & Ország & Mintanagyság & $\begin{array}{l}\text { Tárgykörök és } \\
\text { itemek száma }\end{array}$ & Válaszadási arány & Chronbach Alfa \\
\hline $\begin{array}{l}\text { Pleasant, A., } \\
2008\end{array}$ & Public Health Literacy Knowledge Scale & USA & 829 & $13 / 17$ & $75 \%$ & 0,80 \\
\hline $\begin{array}{c}\text { O'Connor, M., } \\
2015\end{array}$ & Mental Health Literacy Scale & Ausztrália & 372 & $7 / 35$ & nincs adat & 0,80 \\
\hline $\begin{array}{l}\text { Schrauben, S.J., } \\
2017\end{array}$ & Zambia's Health Literacy Scale & Zambia & 13,646 & $4 / 15$ & nincs adat & 0,68 \\
\hline $\begin{array}{l}\text { Jordan, J.E., } \\
2013\end{array}$ & Health Literacy Management Scale & Ausztrália & 542 & $8 / 29$ & $61 \%$ & $>0,82$ \\
\hline $\begin{array}{l}\text { McCormack, L, } \\
2010\end{array}$ & Health Literacy Skills Instrument & USA & 1559 & $5 / 25$ & $71 \%$ & 0,86 \\
\hline $\begin{array}{l}\text { Haghdoost, } \\
\text { A.A., } 2015\end{array}$ & Iranian Health Literacy Questionnaire & Irán & 1080 & $10 / 36$ & $91 \%$ & $0,71-0,96$ \\
\hline Chinn, D., 2013 & All Aspects of Health Literacy Scale & Egyesült Királyság & 146 & $3 / 14$ & nincs adat & 0,75 \\
\hline Suka, M., 2013 & 14-item Health Literacy Scale & Japán & 1507 & $3 / 14$ & $96,4-99,5 \%$ & 0,83 \\
\hline Tsai, T.I., 2011 & Mandarin Health Literacy Scale & Kína & 323 & $5 / 50$ & $72,1 \%$ & 0,97 \\
\hline $\begin{array}{l}\text { Sørensen, K., } \\
2013\end{array}$ & $\begin{array}{l}\text { European Health Literacy Survey } \\
\text { Questionnaire }\end{array}$ & Hollandia & 99 & $12 / 47$ & $95 \%$ & $0,51-0,91$ \\
\hline $\begin{array}{c}\text { Intarakamhang, } \\
\text { U., } 2016\end{array}$ & $A B C D E$ & Thaiföld & 4401 & $8 / 64$ & $97,8 \%$ & $0,61-0,91$ \\
\hline
\end{tabular}

